\title{
Use of Amplified Fragment Length Polymorphism and Sequence Characterized Amplified Region Marker for Identifying the Sex of the Oxyeleotris marmorata
}

\author{
Douglas Law ${ }^{1}$, Voon Chun Ping 2 , Tan Chin Yee², Herryawan Ryadi Eziwar Dyari, \\ Maizan Haiji Mohamed ${ }^{4}$, Shazrul Fazry ${ }^{1}$ and Nik Marzuki Sidik** \\ ${ }^{1}$ Jabatan Sains Makanan, Fakulti Sains dan Teknologi, Universiti Kebangsaan Malaysia, \\ 43600 Bangi, Selangor, Malaysia \\ ${ }^{2}$ Pusat Pengajian Biosains dan Bioteknologi, Fakulti Sains dan Teknologi, Universiti Kebangsaan Malaysia, \\ 43600 Bangi, Selangor, Malaysia \\ ${ }^{3}$ Jabatan Sains Bumi dan Teknologi, Universiti Kebangsaan Malaysia, 43600 Bangi, Selangor, Malaysia \\ ${ }^{4}$ Fakulti Industri Asas Tani, Universiti Malaysia Kelantan, Kampus Jeli, 17600 Jeli, Kelantan, Malaysia
}

\begin{abstract}
There is a huge demand for the Oxyeleotris marmorata, especially in Asian markets. However, farmers are unable to provide a constant supply of this fish to meet the demand, which is estimated to be around 100 metric tonnes per annum. One of the reasons that are hindering the supply is the low success rate of $O$. marmorata breeding programs. These breeding programs rely on many factors for their success, one of which is the use of genuine male and female adults, although determining these could be a daunting task. This research was carried out in an attempt to determine a sex marker for the O. marmorata using the amplified fragment length polymorphism (AFLP) method. Of the $30 \times 30$ AFLP primer mixtures screened, the E-TAA and M-CTT primer pair had an amplified $\sim 600$ bp marker that was specific to the female. This $\sim 600$ bp AFLP marker was later used to design

ARTICLE INFO

Article history:

Received: 03 August 2020

Accepted: 23 November 2020

Published: 24 February 2021

DOI: https://doi.org/10.47836/pjtas.44.1.06

$\overline{\text { E-mail addresses: }}$

douglas.law@gmail.com (Douglas Law)

voonvincent96@gmail.com (Voon Chun Ping)

cyeeanno@gmail.com (Tan Chin Yee)

a 464 bp sequence characterized amplified region (SCAR) marker. Thus, it has been suggested that the SCAR marker obtained has the potential to be used for the sexual identification of the $O$. marmorata at the juvenile stage, thereby enabling them to be used in breeding programs.
\end{abstract}

herry@ukm.edu.my (Herryawan Ryadi Eziwar Dyari)

maizan.m@umk.edu.my (Maizan Haiji Mohamed)

shazrul@ukm.edu.my (Shazrul Fazry)

nikmarzuki@umk.edu.my (Nik Marzuki Sidik)

* Corresponding author
Keywords: AFLP, Oxyeleotris marmorata, sex determination, sex marker 


\section{INTRODUCTION}

In several Asian countries such as China, Thailand, Vietnam, and Malaysia, the Oxyeleotris marmorata (marble goby) is conventionally raised in cages located in freshwater waterways and ponds. It fetches between USD 20/kg to USD 50/kg in Asian markets (Herawati et al., 2016; Yong et al., 2013). Due to its pricey market value, the $O$. marmorata has the potential to be raised as an alternative profitable aquaculture species. Multiple efforts have been undertaken by various parties to perfect the culturing technique for the $O$. marmorata (Lam et al., 2014a, 2014b; Seetapan et al., 2012). However, the sexing of the O. marmorata is one of the biggest challenges faced by farmers in culturing this fish. False sexing of this fish will lead to failure in producing proper brood stocks for the breeding program. What is more challenging is that a system for determining the sex of this fish remains elusive.

The sexual dimorphism of the adult $O$. marmorata can be determined by observing the morphometric differences in its urogenital papilla, caudal fin and caudal peduncle. The female has a longer urogenital papilla in comparison to the male. On the other hand, both the caudal fin and caudal peduncle of the male are longer than those of the female (Idris et. al., 2012). The longer urogenital papilla observed in the female $O$. marmorata is attributed to the need to fulfil the spawning ritual, during which; the female uses its urogenital papilla to deposit its eggs on the surface of a substance. The longer caudal fin and caudal peduncle observed in the male $O$. marmorata are needed for adequate agitation and aeration for the mixing and milting of the eggs during the fertilization process (Idris et. al., 2012). This sexual dimorphism, however, is sometimes hard to determine by the untrained eye and can sometimes lead to false sexing in the field or farm.

In this study, the amplified fragment length polymorphism (AFLP) technique (Vos et. al., 1995) was proposed for the sex-specific marker identification of the O. marmorata using genomic DNA obtained from phenotypically sex-based morphometric features (Idris et al., 2012). The advantages of the AFLP are that it can be conducted without any prior sequence information; it has pre-designed generic primers, and a high multiplexing ratio. The AFLP had previously been successfully utilised for the sex identification of various organisms, including fishes such as the Acipenser schrenckii, Clarias gariepinus, Scophthalmus maximus, Dicentrarchus labrax, Hypophthalmichthys nobilis, Hypophthalmichthys molitrix, Pseudobagrus ussuriensis, Pelteobagrus fulvidraco, and Oncorhynchus mykiss (Cheng et al., 2013; Felip et al., 2000, 2005; Kovács et al., 2000; Liu et al., 2018; Pan et al., 2015; Vale et al., 2014; Xiao et al., 2014). To enable the sex marker to be used in breeding programs on a large scale in a more cost-efficient and labour-intensive manner, the AFLP marker was converted into a polymerase chain reaction-based marker such as the SCAR marker for marker-associated selections (Wang et al., 2011). 
MATERIALS AND METHODS

\section{Oxyeleotris marmorata Source and Genomic DNA Isolation}

A total of 14 adult $O$. marmorata were collected from Empangan Kelau, Bentong Pahang, Malaysia (Coordinates $3^{\circ} 34^{\prime}$ 40.9224"N 101 59'17.7504" E) using both fish traps and gill nets in the months of May 2018 and March 2019. The fish samples were kept alive at the Makmal Genomik 1, Universiti Kebangsaan Malaysia. The fish were kept in fish tank equipped with proper aeration and were fed once a day ad libitum with live feed. The determination of the sex of the $O$. marmorata was based on their morphometric features, as described by Idris et al. (2012). The lengths of the adult fish used in this study were between 20 to $30 \mathrm{~cm}$, while their average weight was $300 \mathrm{~g}( \pm 30 \mathrm{~g})$. The fish were separated into two groups. The first group, comprising 3 females and 3 males, was used for the construction of the gene pool, while the second group, comprising 4 males and 4 females, was used to verify the isolated sex markers. The care of the fish and all the experiments were conducted in compliance with the UKM Animal Ethics Guidelines, as approved by the UKM Ethics Committee (Animal Ethics approval number: FST/2018/ MOHDSHAZRUL/28-MAR./905-MAR2018-AUG-2019) on 11 April 2018. All the fish were euthanized at the end of the experiments using methods previously described by Blessing et al. (2010). The sexual organs were also observed to confirm the gender of the fish.
The genomic DNA was isolated from the caudal fin of the fish, according to the phenolchloroform method with modifications (Sambrook et al., 1989). About $0.5 \mathrm{~g}$ of the caudal fin was taken from the $O$. marmorata and preserved in $95 \%$ ethanol immediately after collection for storage prior to the genomic extraction process. The preserved sample was frozen using liquid nitrogen prior to homogenisation using a pre-chilled mortar and pestle. A total volume of $500 \mu \mathrm{L}$ of extraction buffer (10 mM EDTA, $100 \mathrm{mM}$ Tris- $\mathrm{HCl}, 200 \mathrm{mM} \mathrm{NaCl}$, and $0.7 \%$ SDS) were added to the homogenised sample. The mixture was vortexed for 30 seconds. Proteinase K $(50 \mu \mathrm{g})$ was added, and the mixture was incubated for 60 minutes at $50^{\circ} \mathrm{C}$. Next, $650 \mu \mathrm{L}$ of phenol, chloroform and isoamyl alcohol (25:24:1) were added to the sample, after which, the mixture was vortexed for 30 seconds, followed by centrifugation at $4^{\circ} \mathrm{C}$ for 5 minutes at a speed of $12,000 \mathrm{xg}$. Later, the aqueous phase was transferred into a fresh tube, and the same volume of chloroform and isoamyl alcohol (24:1) was added to the sample. The mixture was vortexed for 30 seconds, followed by centrifugation at $4{ }^{\circ} \mathrm{C}$ for 5 minutes at a speed of $12,000 \mathrm{xg}$. The aqueous phase was transferred into a fresh tube, and two volumes of ethanol were added to the sample. The mixture was inverted several times and was incubated at $-20^{\circ} \mathrm{C}$ for 16 to 20 hours. The mixture was then centrifuged at $4{ }^{\circ} \mathrm{C}$ for 10 minutes at a speed of 12,000 $\mathrm{xg}$. The pellet was washed in $70 \%$ cold ethanol. The sample was then dried, and resuspended in sterile $\mathrm{dH}_{2} \mathrm{O}$ containing 
RNase A $(10 \mu \mathrm{g} / \mathrm{mL})$. The quality of all the genomic DNA obtained was checked using a NanoDrop ${ }^{\text {TM }}$ Spectrophotometer ND-2000. Only the genomic DNA at a 260/280 ratio of 1.8 and above was used for all the assays.

\section{AFLP Reaction Assay}

Approximately $0.5 \mathrm{mg}$ of genomic DNA from the first fish group was digested and ligated simultaneously at room temperature overnight using $0.5 \mathrm{M}$ of $\mathrm{NaCl}, 5 \mathrm{U}$ EcoRI (Promega Corporation), $10 \mathrm{U}$ MseI (New England Biolabs), $0.55 \mu \mathrm{L}(1.0 \mathrm{mg} / \mathrm{mL})$ of $100 \times \mathrm{BSA}, 1 \mu \mathrm{L}$ of $\mathrm{Mse}$ I adapter $(20 \mathrm{pmol} /$ $\mu \mathrm{L}), 1 \mu \mathrm{L}$ of $E c o$ RI adapter $(20 \mathrm{pmol} / \mu \mathrm{L})$, $200 \mathrm{U}$ T4 DNA ligase (Promega), $1.1 \mu \mathrm{L}$ of T4 DNA ligase buffer, and $5.5 \mu \mathrm{L}$ of distilled water. The digested and ligated mixture was then diluted to $200 \mu \mathrm{L}$ with Tris-EDTA buffer (20mM Tris-HCl, 0.1 mM EDTA) and kept at $-20^{\circ} \mathrm{C}$ for use in the pre-amplification process.

For the pre-amplification process, a mixture was prepared with the following content: $7.5 \mu \mathrm{L}$ of ligated DNA, $2.0 \mu \mathrm{L}$ of $10 \times \mathrm{Taq}$ polymerase buffer, $0.6 \mu \mathrm{L}$ of $50 \mathrm{mM} \mathrm{MgCl}, 0.5 \mu \mathrm{L}$ of $10 \mathrm{mM}$ dNTPs (Invitrogen), $0.25 \mu \mathrm{L}$ of EcoRI preamplification primer $(20 \mathrm{pmol} / \mu \mathrm{L}), 0.25 \mu \mathrm{L}$ of MseI pre-amplification primer (20 pmol/ $\mu \mathrm{L}), 2.5 \mathrm{U}$ Taq polymerase (Invitrogen) and distilled water, to make a final volume of $20 \mu \mathrm{L}$. The cycling parameters used for the pre-amplification process were $94^{\circ} \mathrm{C}$ for 5 minutes, followed by 20 cycles at $94^{\circ} \mathrm{C}$ for 45 seconds, $56^{\circ} \mathrm{C}$ for 30 seconds, and $72^{\circ} \mathrm{C}$ for 2 minutes, followed by a final extension at $72^{\circ} \mathrm{C}$ for 30 minutes. The pre- amplification products were then diluted to $100 \mu \mathrm{L}$ with Tris-EDTA buffer (20 mM Tris$\mathrm{HCl}, 0.1 \mathrm{mM}$ EDTA) and kept at $-20^{\circ} \mathrm{C}$ for use in the selective amplification process.

Each $10 \mu \mathrm{L}$ of the mixture for the selective amplification reaction contained $0.5 \mu \mathrm{L}$ of the pre-amplified products, 1.0 $\mu \mathrm{L}$ of $10 \times \mathrm{Taq}$ polymerase buffer, $0.6 \mu \mathrm{L}$ of $50 \mathrm{mM} \mathrm{MgCl} 2,0.5 \mu \mathrm{L}$ of $10 \mathrm{mM}$ dNTPs (Invitrogen), $1 \mu \mathrm{L}$ of EcoRI +3 primer (10 $\mathrm{pmol} / \mu \mathrm{L}), 0.25 \mu \mathrm{L}$ of $M s e \mathrm{I}+3$ primers (10 pmol $/ \mu \mathrm{L}), 2.5 \mathrm{U}$ of Taq polymerase (Invitrogen) and distilled water to make a final volume of $10 \mu \mathrm{L}$. The AFLP products were amplified using touchdown PCR. Stage 1: $94^{\circ} \mathrm{C}$ for 5 minutes (1 cycle); Stage 2: $94^{\circ} \mathrm{C}$ for 45 seconds, $65^{\circ} \mathrm{C}$ for 30 seconds, and $72^{\circ} \mathrm{C}$ for 2 minutes. The annealing temperature was then lowered by $1.0^{\circ} \mathrm{C}$ per cycle (10 cycles); Stage $3: 94^{\circ} \mathrm{C}$ for 30 seconds, $56^{\circ} \mathrm{C}$ for 30 seconds, and $72^{\circ} \mathrm{C}$ for 2 minutes (20 cycles); and this was followed by a final extension stage at $72{ }^{\circ} \mathrm{C}$ for 15 minutes. The selective amplification products were separated in $1.5 \%$ agarose.

The sex-specific fragments were excised and purified from the agarose gel using NucleoSpin ${ }^{\circledR}$ Gel and PCR Clean-up Kit (MACHEREY-NAGEL), and were sent to Apical Sdn. Bhd. for sequencing.

\section{Adaptation of AFLP Marker as SCAR Marker}

Primer blast (NCBI) software was used in designing the SCAR primers for the AFLP marker sequences. These primers were used to amplify the genomic DNA of the second group of fishes, consisting of four males and 
4 females. The SCAR reaction was carried out in $2.0 \mu \mathrm{L}$ of $10 \times \mathrm{PCR}$ reaction buffer, $0.5 \mu \mathrm{L}$ of $25 \mathrm{mM} \mathrm{MgCl} 2,0.6 \mu \mathrm{L}$ of $2 \mathrm{mM}$ dNTPs, 20 pmol each of forward and reverse primers, $0.5 \mu \mathrm{L}$ of genomic DNA, $2.0 \mathrm{U}$ Taq polymerase, $0.5 \mu \mathrm{L}$ of genomic DNA and distilled water to bring it to a volume of $20 \mu \mathrm{L}$. The cycling parameters used were $94^{\circ} \mathrm{C}$ for 5 minutes, followed by 30 cycles at $94^{\circ} \mathrm{C}$ for 45 seconds, optimised annealing temperature for 45 seconds, $72^{\circ} \mathrm{C}$ for 75 seconds, and final extension cycle at $72^{\circ} \mathrm{C}$ for 15 minutes. All the PCR products were examined in $1.5 \%$ agarose to determine the success of the SCAR primer conversion.

\section{RESULTS AND DISCUSSIONS}

Combinations of $30 \times 30$ AFLP primer pairs (Appendix 1) were used to screen potential sex markers from groups of males and females of the $O$. marmorata genomic DNA. To verify that these markers were associated to the genomic sex DNA sequences, the genomic DNA from 6 male and female $O$. marmorata were used as the DNA templates for these primer pairs (Figure 1). The study showed that only the E-TAA and M-CTT primer pair specifically amplified the DNA amplicon size of $\sim 600 \mathrm{bp}$ from the female genomic DNA, making it a specific marker for the female $O$. marmorata. The $\sim 600$ bp amplicon was sequenced, giving $574 \mathrm{bp}$. The sequence was deposited at the GenBank with accession number: MW148239. However, from the nucleotide BLAST analysis that was done, the sequence revealed that the amplicon did not contain any homology to any other species sequence in the GenBank database (data not shown). The non-homology sequence was expected as the AFLP is able to detect random DNA variations and highly likely non-coding DNA (Figure 2).

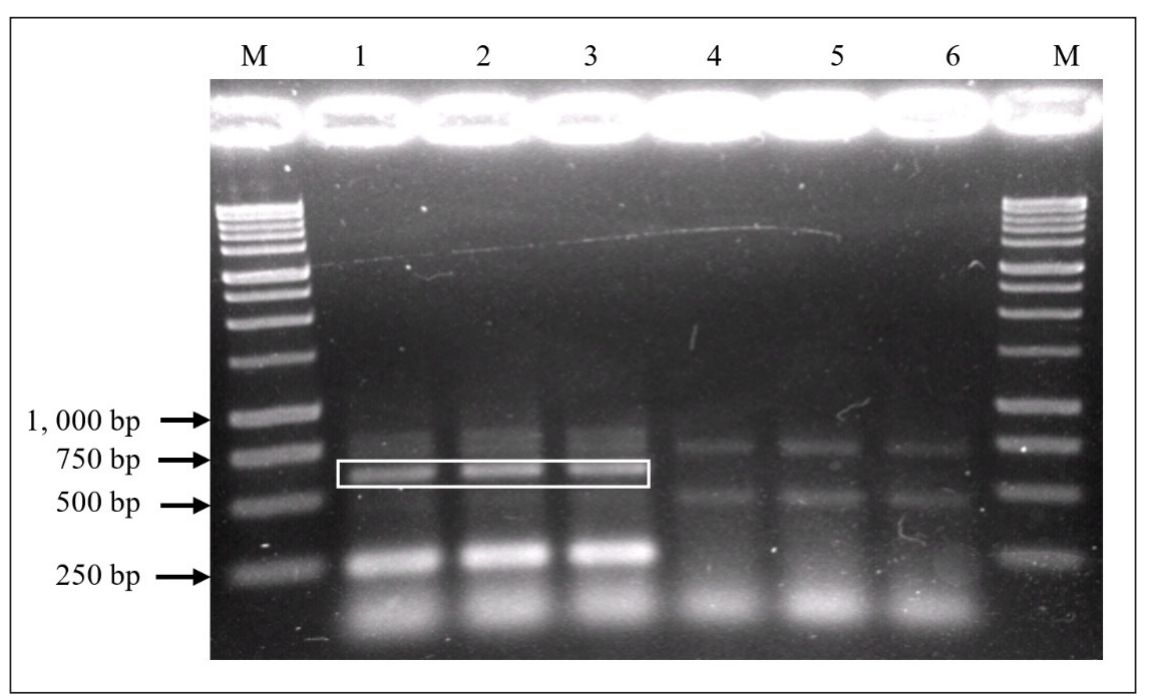

Figure 1. A $\sim 600 \mathrm{bp}$ band of the female-specific AFLP marker discovered with the E-TAA/M-CTT primer pair (marked in white box). Lanes 1 to 3 are the female samples; Lanes 4 to 6 are the male samples; Lane M is $1 \mathrm{~kb}$ DNA ladder marker 
A primer pair (SM 1: 5, GTCGGAATGTACCAAAGACAT 3' and SM2: 5'TATGAGTCCGTGAGTAACGC 3 ') was designed based on the sequence obtained from the female specific AFLP fragment from the E-TAA/M-CTT primer pair screening. The designed primer pair optimal annealing temperature was at $54^{\circ} \mathrm{C}$, producing the expected $\sim 480 \mathrm{bp}$ amplicon, which was observed only in the female $O$. marmorata, but not in any male $O$. marmorata sample (Figure 3).
As far as is known, this is the first ever reported sex marker for the Oxyeleotris marmorata determined through the AFLP. The identified specific sex marker has multiple possible uses in basic research and commercial brood stock raising (Purcell et al., 2018). In basic research, the characterization of a sex marker for mature O. marmorata can provide invaluable data for understanding the sex determination mechanism. In commercial brood stock raising of the $O$. marmorata, the fish require

1 GACTGCGTAC CAATTCTAAg AACCATAATA CATAAAgAAC AGgGCGAgCG GACAgCTCCC 60

61 GGGCTCCATC CCTCCGGGGA GGCCCAACGT GTCGGAATGT ACCAAAGACA TCTATTATAC 120 SM1

121 GgCCGAATCC TTAGATTTGA GCATCACTCC TCTCGCTGTg CGACACCCGg CGTATCTGAA 180

181 AgACACTTCG CACTTCATAG AGTCCATAAT GGATCTGCAC GTCCCGGGAG ACGCCTTCTT 240

241 CTTCTCCCTG GACATTGACT CTTTAAATAC CAACATTCCC ATCCAGGCCG GCATTCAGGC 300

301 CGTCAGAGAA ATTTTCCAAC TGTACCCTGA CCCCGCCAGG CCGGACGCGG AGCTCCTCCG 360

361 GTTACTGGAG ATCAATTTGA CTAAGAACGA CTTTGTCTTT GACGGCAAGT TCTACCTCCA 420

421 GGTCAAAGG ACCGCCATGG GCAAACGCTT TGCCCCCGCT TACGCTAATA TCTTCATGGC 480

481 CAAATGGGAA AGACAAGTAC TGGCCACCTG CCCTAAAAAA CCGCTGCACT ACCTGCGTTA 540

541 CTCACGGACT CATACAAGTT ACTCAGGACT CATC SM2

Figure 2. The female-specific AFLP marker sequence and bold section indicate the primer designed for the SCAR marker

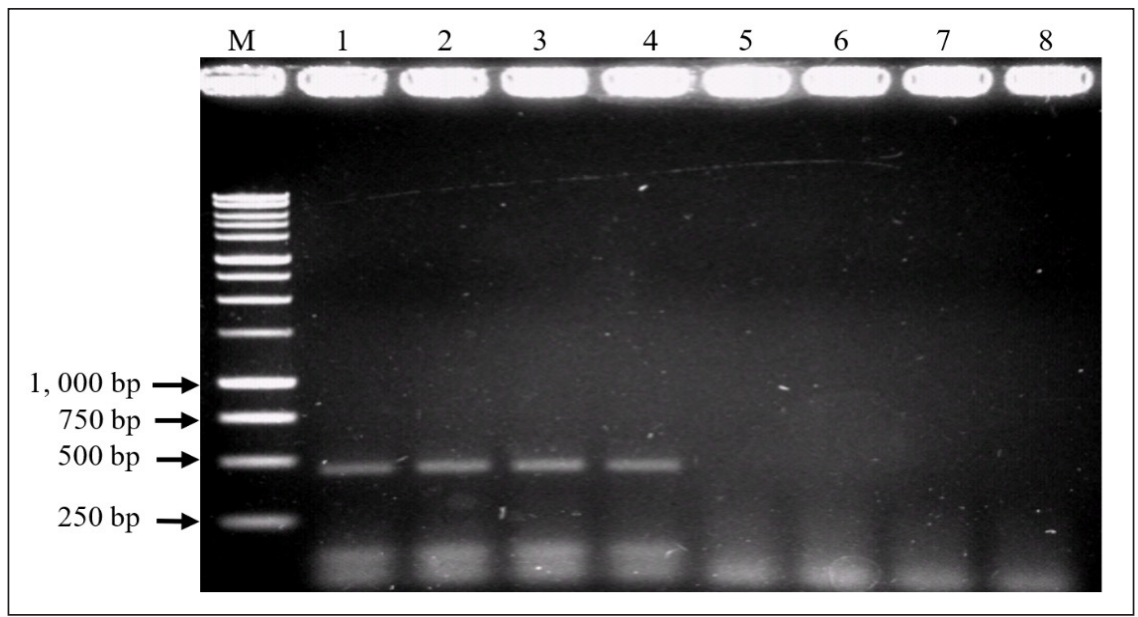

Figure 3. The SCAR marker for Oxyeleotris marmorata sexes determination. A 480 bp band is present in the females (F) but not in the males (M). Lanes 1 to 4 are female sample. Lanes 5 to 8 are male sample. Lane M, $1 \mathrm{~kb}$ DNA ladder marker 
almost 2 years before sexual identification can be done based on their reproductive organs, and only a highly-trained and experienced person will be able to do this as there are different distinct numbers of brood stocks to be maintained between the two sexes (Idris et al., 2012). Therefore, it will be more efficient and economical, in the long run if early sex identification can be done through molecular methods without having to wait for the fish to enter the maturity phase (Al-Ameri et al., 2016).

\section{CONCLUSION}

This study has succeeded in determining a female-specific AFLP and SCAR marker for Oxyeleotris marmorata samples from Tasik Klau, Bentong, Pahang. Both the female-specific AFLP and SCAR marker can be potentially used as a quick method for determining the sex of the O. marmorata for their potential use at the juvenile stage, thereby reducing the time and economic resources required to breed the species for commercialisation.

\section{ACKNOWLEDGEMENTS}

The authors would like to thank the Malaysia Ministry of Higher Education (FRGS:A07.0 0/01543A/001/201700436) for funding this research activity. The authors are grateful to the Makmal Genomik 1, Faculty of Science and Technology, Universiti Kebangsaan Malaysia for providing facilities throughout the research period.

\section{REFERENCES}

Al-Ameri, A. A., Al-Qurainy, F., Gaafar, A. R. Z., Khan, S., \& Nadeem, M. (2016). Molecular identification of sex in Phoenix dactylifera using inter simple sequence repeat markers. BioMed Research International, 2016, 4530846. https:// doi.org/10.1155/2016/4530846

Blessing, J. J., Marshall, J. C., \& Balcome, S. R. (2010). Humane killing of fishes for scientific research: A comparison of two methods. Journal of Fish Biology, 76(10), 2571-2577. https://doi. org/10.1111/j.1095-8649.2010.0263 3.x

Cheng, D., Mei, J., Wang, D., \& Gui, J. F. (2013). Genetic differentiation and efficient sex-specific marker development of a pair of Y- and X-linked markers in yellow catfish. International Journal of Biological Science, 9(10), 1043-1049. https:// doi.org/10.7150/ijbs.7203

Felip, A., Martinez-Rodriguez, G., Piferrer, F., Carrillo, M., \& Zanuy, S. (2000). AFLP analysis confirms exclusive maternal genomic contribution of meiogynogenetic sea bass (Dicentrarchus labrax L.). Marine Biotechnology, 2(3), 301-3066. https://doi.org/10.1007/s101260000000

Felip, A., Young, W. P., Wheeler, P. A., \& Thorgaard, G. H. (2005). An AFLP-based approach for the identification of sex-linked markers in rainbow trout (Oncorhynchus mykiss). Aquaculture, 247(1-4), 35-43. https://doi.org/10.1016/j. aquaculture.2005.02.014

Herawati, T., Yustiati, A., Nurhayati, A., \& Natadia, S. S. (2016). Domestication of marble goby [Oxyeleotris marmorata (Bleeker, 1852)] indogenous fish of Citarum River, Indonesia. Aquatic Procedia, 7, 247-253. https://doi. org/10.1016/j.aqpro.2016.07.035

Idris, H. B., Ambak, M. A., \& Ikhwanuddin, M. (2012). Sex determination in Oxyeleotris marmorata (Bleeker, 1852) based on morphometric features. Advances in Natural Applied Sciences, 6(6), 763-771. 
Douglas Law, Voon Chun Ping, Tan Chin Yee, Herryawan Ryadi Eziwar Dyari, Maizan Haiji Mohamed, Shazrul Fazry and Nik Marzuki Sidik

Kovács, B., Egedi, S., Bártfai, R., \& Orbán, L. (2000). Male-specific DNA markers from African catfish (Clarias gariepinus). Genetica, 110(3), 267-276. https://doi.org/10.1023/A:1012739318941

Lam, S. S., Ambak, M. A., Jusoh, A., \& Law, A. T. (2014a). Growth performance and waste excretion of marble goby (Oxyeleotris Marmorata Bleeker) in relation to different culture system and diet. Aquaculture, 29(1), 41-45. https://doi.org/10.1016/ j.aquaculture. 2007.11 .023

Lam, S. S., Ma, N. L., Jusoh, A., \& Ambak, M. A. (2014b). A study on the optimal tank design and feed type to the growth of marble goby (Oxyeleotris marmorata Bleeker) and reduction of waste in a recirculating aquaponic system. Desalination and Water Treatment, 52(4), 1044-1053. https://doi.org/10.1080/19443994. 2013.826854

Liu, H., Pang, M., Yu, X., Zhou, Y., Tong, J., \& Fu, B. (2018). Sex-specific markers developed by next-generation sequencing confirmed an XX/ $\mathrm{XY}$ sex determination system in bighead carp (Hypophthalmichehys nobilis) and silver carp (Hypophthalmichthys molitrix). DNA Research, 25(3), 257-264. https://doi.org/10.1093/dnares/ dsy009

Pan, Z. J., Li, X. Y., Zhou, F. J., Qiang, X. G., \& Gui, J. F. (2015). Identification of sexspecific markers reveals male heterogametic sex determination in Pseudobagrus ussuriensis. Marine Biotechnology, 17(4), 441-451. https:// doi.org/10.1007/s10126-015-9631-2

Purcell, C. M., Seetharam, A. S., Snodgrass, O., Ortega-García, S., Hyde, J. R., \& Severin, A. J. (2018). Insights into teleost sex determination from the Seriola dorsalis genome assembly. BMC Genomics, 19(1), 31. https://doi.org/10.1186/ s12864-017-4403-1
Sambrook, J., Fritsch, E. F., \& Maniatis, T. (1989). Molecular cloning: A laboratory manual $\left(2^{\text {nd }}\right.$ ed.). Cold Spring Harbour Press.

Seetapan, K., Puanglarp, N., \& Meunpol, O. (2012, November 22-24). Study of optimal culture conditions for juvenile marble goby (Oxyeleotris marmorata Bleeker, 1852) [Paper presentation]. Proceedings of $2^{\text {nd }}$ the Annual International Conference Syiah Kuala University-Life Sciences and Engineering, Banda Aceh, Indonesia. http://jurnal.unsyiah.ac.id/AICSSciEng/article/view/1713/1611

Vale, L., Dieguez, R., Sánchez, L., Martínez, P., \& Viñas, A. (2014). A sex-associated sequence identified by RAPD screening in gynogenetic individuals of turbot (Scophthalmus maximus). Molecular Biology Report, 41(3), 1501-1509. https://doi.org/10.1007/s11033-013-2995-3

Vos, P., Hoger, R., \& Blecker, M. (1995). AFLP: A new technique for DNA fingerprinting. Nucleic Acids Research, 23(21), 4407-4414. https://doi. org/10.1093/nar/23.21.4407

Wang, D. W., Li, Y., \& Li, Z. Q. (2011). Identification of a male-specific amplified fragment length polymorphism (AFLP) and a sequence characterized amplified region (SCAR) marker in Eucommia ulmoides Oliv. International Journal of Molecular Sciences, 12(1), 857-864. https:// doi.org/10.3390/ijms12010857

Xiao, T. Q., Lu, C. Y., Li, C., Cheng, L., Cao, D. C., $\&$ Sun, X. W. (2014). An AFLP-based approach for the identification of sex-linked markers in Amur sturgeon Acipenser schrenckii Brandt, 1869. Journal of Applied Ichthyology, 30(6), 1282-1285. https://doi.org/10.1111/jai.12553

Yong, S., Ooi, S., \& Shapawi, R. (2013). The utilization of soybean meal in formulated diet for marble goby, Oxyeleotris marmoratus. Journal of Agricultural Science, 5(11), 139-149. https:// doi.org/10.5539/jas.v5n11p139 


\section{APPENDIX 1}

Supplementary Table

List of AFLP primer pairs used in the screening

\begin{tabular}{|c|c|c|c|}
\hline No. & EcoRI AFLP primers (E-XXX) & No. & MseI AFLP primers (M-XXX) \\
\hline 1 & *5' GACTGCGTACCAATTCTAA 3' & 1 & 5' GATGAGTCCTGAGTAAACA 3' \\
\hline 2 & 5' GACTGCGTACCAATTCTAT 3' & 2 & 5' GATGAGTCCTGAGTAAACT 3' \\
\hline 3 & 5' GACTGCGTACCAATTCTAC 3' & 3 & 5' GATGAGTCCTGAGTAAACC 3' \\
\hline 4 & 5' GACTGCGTACCAATTCTAG 3' & 4 & 5' GATGAGTCCTGAGTAAACG 3' \\
\hline 5 & 5' GACTGCGTACCAATTCTTA 3' & 5 & 5' GATGAGTCCTGAGTAAAGA 3' \\
\hline 6 & 5' GACTGCGTACCAATTCTTT 3' & 6 & 5' GATGAGTCCTGAGTAAAGT 3' \\
\hline 7 & 5' GACTGCGTACCAATTCTTC 3' & 7 & 5' GATGAGTCCTGAGTAAAGC 3' \\
\hline 8 & 5' GACTGCGTACCAATTCTTG 3' & 8 & 5' GATGAGTCCTGAGTAAAGG 3' \\
\hline 9 & 5' GACTGCGTACCAATTCTCA 3' & 9 & 5' GATGAGTCCTGAGTAACAA 3' \\
\hline 10 & 5' GACTGCGTACCAATTCTCT 3' & 10 & 5' GATGAGTCCTGAGTAACAT 3' \\
\hline 11 & 5' GACTGCGTACCAATTCTCC 3' & 11 & 5' GATGAGTCCTGAGTAACAC 3' \\
\hline 12 & 5' GACTGCGTACCAATTCTCG 3' & 12 & 5' GATGAGTCCTGAGTAACAG 3' \\
\hline 13 & 5' GACTGCGTACCAATTCTGA 3' & 13 & 5' GATGAGTCCTGAGTAACTA 3' \\
\hline 14 & 5' GACTGCGTACCAATTCTGT 3' & 14 & *5' GATGAGTCCTGAGTAACTT 3' \\
\hline 15 & 5' GACTGCGTACCAATTCTGC 3' & 15 & 5' GATGAGTCCTGAGTAACTC 3' \\
\hline 16 & 5' GACTGCGTACCAATTCTGG 3' & 16 & 5' GATGAGTCCTGAGTAACTG 3' \\
\hline 17 & 5' GACTGCGTACCAATTCAAA 3' & 17 & 5' GATGAGTCCTGAGTAACCA 3' \\
\hline 18 & 5' GACTGCGTACCAATTCAAT 3' & 18 & 5' GATGAGTCCTGAGTAACCT 3' \\
\hline 19 & 5' GACTGCGTACC AATTCAAC 3' & 19 & 5' GATGAGTCCTGAGTAACCC 3' \\
\hline 20 & 5' GACTGCGTACCAATTCAAG 3' & 20 & 5' GATGAGTCCTGAGTAACCG 3' \\
\hline 21 & 5' GACTGCGTACCAATTCATA 3' & 21 & 5' GATGAGTCCTGAGTAACGA 3' \\
\hline 22 & 5' GACTGCGTACCAATTCATT 3' & 22 & 5' GATGAGTCCTGAGTAACGT 3' \\
\hline 23 & 5' GACTGCGTACCAATTCATC 3' & 23 & 5' GATGAGTCCTGAGTAACGC 3' \\
\hline 24 & 5' GACTGCGTACCAATTCATG 3' & 24 & 5' GATGAGTCCTGAGTAACGG 3' \\
\hline 25 & 5' GACTGCGTACCAATTCACA 3' & 25 & 5' GATGAGTCCTGAGTAAGAA 3' \\
\hline 26 & 5' GACTGCGTACCAATTCACT 3' & 26 & 5' GATGAGTCCTGAGTAAGAT 3' \\
\hline 27 & 5' GACTGCGTACCAATTCACC 3' & 27 & 5' GATGAGTCCTGAGTAAGAC 3' \\
\hline 28 & 5' GACTGCGTACCAATTCACG 3' & 28 & 5' GATGAGTCCTGAGTAAGAG 3' \\
\hline 29 & 5' GACTGCGTACCAATTCAGA 3' & 29 & 5' GATGAGTCCTGAGTAAGTA 3' \\
\hline 30 & 5' GACTGCGTACCAATTCAGT 3' & 30 & 5' GATGAGTCCTGAGTAAGTT 3' \\
\hline
\end{tabular}

Note.

1. XXX represent the last 3 nucleotides of the primer

2. * The AFLP selective-primer pairs that were used for development of SCAR marker 
